\title{
CONTEMPORARY ASPECTS OF LEGAL APPROXIMATION BETWEEN THE EUROPEAN UNION AND THE RUSSIAN FEDERATION
}

\author{
Dmitriy V. Galushko, PhD, Associate Professor \\ Voronezh State University, International and Eurasian Law Department \\ 1 Universitetskaya pl., Voronezh, 394018, Russia \\ galushkodv@gmail.com
}

\begin{abstract}
Legal harmonization has been playing a central part in international relations from the second half of the XX century. This was caused by the intensification of cooperation in the economic sphere between both public and private actors from different countries. This can be seen in an example of the European Union and the Russian Federation. The goal of legal approximation of the EU law with the Russian legal system was inscribed in the Partnership and Cooperation Agreement between the European Communities and the Russian Federation.

Russia, like many countries that are not member states of the European Union, has been making efforts to approximate their national legislation to norms of the EU legal system. Legislative approximation of the EU law means transposition, implementation, and enforcement of the norms of the EU legal system in their partner countries' national legal practices; a legislative process that aims gradually to bring closer and eventually to bring into compliance partner countries' legislative framework with EU law.

The research is focused on the study of modern issues of approximation between legal orders of the European Union and the Russian Federation with stress on particular branches of law, which was influenced by the process. The author starts from the evolution of the approximation process, its general issues, development of a relevant international legal basis. Features of influence of the EU on developments of the Russian legal system were identified and analyzed. As the EU-Russia legal approximation process now faces both internal and external-global threats, relevant law, developments of its different spheres and branches of the legal system of the Russian Federation, will be explored. In the focus of research, there will be developments in the following branches: civil law, labor law, technical regulation, legal regulation of higher education. The author finally gives his view on prospects of the EU-Russia legal approximation process, its development in the light of existing and future global and regional challenges and relations.
\end{abstract}

Keywords: approximation, legal harmonization, implementation, the legal system, European Union, Russian Federation 


\section{INTRODUCTION}

The normative sphere occupies a crucial place in relations of the European Union with Russia, however, as with other states. Obviously, in the context of Russian-European relations, Russia is seen as a recipient - an actor called upon to adopt European standards. Bilateral international treaties act as the legal basis for the EU's influence on legal orders of third countries. Moreover, when concluding international agreements with third countries, the EU widely uses the practice of including in these agreements provisions similar to those contained in EU legislation addressed to member states, as well as provisions that require third countries to adapt their legislation to relevant legal acts of the European Union, thereby harmonizing it with the provisions of aquis. This creates the legal basis for the assimilation of the provisions established by EU law, the internal legal orders of third countries. ${ }^{1}$ This is a model of "hierarchical inclusion", ${ }^{2}$ which considers the European Union as a "normative hegemon" 3 and involves the gradual entry of the recipient into the European normative space. ${ }^{4}$

Relations between the European Union and the Russian Federation are a serious test for the "normative power of Europe." This concept, formulated by J. Manners, indicates that the European Union is, first and foremost, values and norms, first of all, such as peace, freedom, democracy, the rule of law and respect for human rights, as well as several secondary ones - social solidarity, non-discrimination, sustainable development, and good governance. ${ }^{5}$ Considering the scale and ambitions of both sides, regulatory cooperation is hardly effective, smooth, and cloudless.

In these conditions the main objective of the contribution is to provide analysis of the normative component of the process of adaptation of Russian national legislation to the legislation of the European Union in particular areas of legal regulation. Taking into consideration this objective the paper will start from consideration of major issues of the EU-Russia law approximation process. Since the approximation process covers various fields of Russian law, attention will be given

See further: Hillion, Ch., The evolving system of the EU external relations as evidenced in the EU partnerships with Russia and Ukraine, Leiden, 2005

2 Haukkala, H.. Debating Recent Theories of EU-Russia Interaction, Cooperation, and Conflict, vol. 43, no. 1,2008 , p. 116

3 Haukkala, H., The European Union as a Regional Normative Hegemon: The Case of European Neighbourhood Policy, Europe-Asia Studies, vol. 60, no. 9, 2008, pp. 1601-1622

4 Yun, S.M. (ed.), Russia and the European Union: Textbook, Tomsk, Publishing house of Tomsk University, 2014, p. 53

5 Manners, I., Normative Power Europe: A Contradiction in Terms? Journal of Common Market Studies, vol. 40, no. 2, 2002, pp. 235-258 
to relevant developments in civil law, legal regulation of the transport sector, labor law and the sphere of technical regulation. Further, the paper elaborates in detail the normative arrangements of Eu-Russia law approximation and some features of the current Russian legislation in the field of higher education through the analysis of the relevant Russian legal sources.

\section{EU-RUSSIA LAW APPROXIMATION: SOME MAJOR REMARKS}

Approximation of the Russian legal system with the legal order of the European Union is primarily based on the Partnership and Cooperation Agreement (PCA) of $1994,{ }^{6}$ by which the concept of creating EU-Russia four common spaces should be implemented: a Common Economic Space; a Common Space of Freedom, Security and Justice; a Common Space of External Security and a Common Space of Research and Education, including Cultural Aspects. ${ }^{7}$ These four spaces should appear based on the PCA and the basis of the tools and mechanisms provided by the PCA. As noted in the Russian doctrine, a tool for approximation of legislation, provided for by Art. 55 of the PCA should also become a reference point for their formation. ${ }^{8}$ The implementation of the relevant provisions of documents on cooperation between the Russian Federation and the EU allows forming the basis for reforming the domestic legal system and its development in the context of the most advanced regulatory trends. This, among other things, can contribute to greater predictability of work in Russia not only for foreign, but also for domestic business, and stimulate investment attraction.?

Some PCA provisions have not been sufficiently implemented so far. Among the main ones, the question of approximation of the legislation should be noted. The Agreement stipulated the gradual ensuring of compatibility of the economic legislation of Russia with the legislation of the European Union as a direction of Russian reforms. Later, in the roadmap on the common economic space and the mechanism of the dialogues created within its framework, this general reference was indirectly interpreted primarily as a task of gradual harmonizing the laws of

6 Agreement on partnership and cooperation establishing a partnership between the European Communities and their Member States, of one part, and the Russian Federation, of the other part, OJ L 327, 28.11.1997, p. 3-69

7 Kashkin, S.Yu., Strategy and mechanisms for harmonizing the legislation of Russia and the European Union as key components of their effective mutual development in the 21st century, Moscow, Russian-European Center for Economic Policy, 2006, p. 10

8 Kashkin S.Yu.; Kalinichenko, P.A., Harmonization of the legislation of Russia and the European Union, as a key component of their effective mutual development in the XXI century, Law and state: theory and practice, 2005, no. 4, p. 103

9 Kulik, S.A., Russia - European Union: On the Forks of "Strategic Partnership", INSOR, 2010, June, [http://www.insor-russia.ru/files/Russia_EU_Kulik_.pdf\#3], Accessed 10 April 2020 
Russia and the European Union based on the legislation of the latter - acquis communautaire. In other words, based on the principle that the EU usually provides for in preferential agreements with third countries or with the prospect of switching to a preferential regime. ${ }^{10}$ However, there is no legal basis for such an interpretation. In fact, Russian legislation has been improved in line with international best practices, including the EU's one.

It should be noted that any references to EU law, the mention of acts of the Union in the texts of Russian legal acts or explanatory notes to them are extremely rare. Nevertheless, their content in some cases in every possible way indicates the use of European regulatory experience, the perception of the norms and institutions of EU law in the legal system of the Russian Federation, the convergence of Russian legislation with EU law. Besides, the membership of Russia in the Council of Europe also makes a significant contribution to the convergence of Russian legislation with European legal norms, because the European Convention on $\mathrm{Hu}$ man Rights and other conventions of this organization establish common legal standards, including for EU member states.

In general, the process of approximating Russian legislation with EU law is too diverse and complicated. Nevertheless, some researchers point to the trend of "Europeanization" of Russian law, ${ }^{11}$ which in the modern era consists of both Europeanizing the Russian legal culture as a whole and modernizing legislation based on European standards and Europeanizing Russian judicial practice. ${ }^{12}$

\section{EFFECTS OF THE EU-RUSSIA APPROXIMATION PROCESS IN VARIOUS FIELDS OF LEGAL REGULATION}

Among the branches in which obvious success in approximating Russian legislation with EU law has been achieved, various institutes of civil law, intellectual property law, competition law, public procurement, state regulation of foreign trade, technical regulation and others can be distinguished.

So, on 18 July 2008, Decree No. 1108 "On improving the Civil Code of the Russian Federation"13 was signed. This document approved the proposal of the

\section{$10 \quad$ Ibid.}

11 See: Kalinichenko, P.A., Europeanization of Russian law, [https://publishup.uni-potsdam.de/opus4ubp/frontdoor/deliver/index/docId/5663/file/belling_online_S65_86.pdf], Accessed 10 April 2020

12 Kazimirova, N.G., Russia in the of continental law: reception and perspectives of reforming of the legislation, Economic, Legal, Social-Political and Psychological Problems of Development of the Modern Society, 2015, pp. 171-175

13 Decree of the President of the Russian Federation "On improving the Civil Code of the Russian Federation” dated July 18, 2008 No. 1108, Rossiyskaya Gazeta, 2008, No. 155 
Presidential Council on the codification and improvement of civil legislation on the development of a concept for the development of civil legislation. ${ }^{14}$ At the same time, among other things, the following goals were proclaimed:

- further development of the basic principles of civil legislation of the Russian Federation;

- reflection in the Civil Code of the experience of its application and interpretation;

- approximation of the provisions of the Civil Code of the Russian Federation with the rules for regulating relevant relations in EU law;

- use in the civil legislation of the Russian Federation the latest positive experience in the modernization of EU civil codes.

Subsequently, on 27 April 2012, the State Duma of the Federal Assembly of the Russian Federation in first reading adopted the draft Federal Law No. 47538-6 "On Amendments to Parts One, Two, Three and Four of the Civil Code of the Russian Federation, as well as to Separate Legislative Acts of the Russian Federation" ${ }^{15}$ which incorporated many provisions and entire institutions of law of the European Union, for example, concerning the introduction of new categories of legal entities, some internal issues of their functioning and activities. This project was developed as part of the implementation of the Civil Law Development Concept, and it was assumed that back in 2012 it would be adopted as a whole and at the same time. However, the project did not receive further promotion. ${ }^{16}$ Later on, it was divided into smaller blocks, which were gradually finalized and adopted in the form of federal laws on amendments to different chapters of the Civil Code. ${ }^{17}$

14 Baltutite, I.V., The contingence of corporate regulation in the being reformed Civil Code of the Russian Federation with the provisions of the Corporate law of the European Union, Science Journal of VolSU, Series 5: Jurisprudence, no. 4, 2013, p. 2

15 Draft Federal Law No. 47538-6 "On Amending the Civil Code of the Russian Federation, Certain Legislative Acts of the Russian Federation and on the Recognition of Certain Legislative Acts (Provisions of Legislative Acts) of the Russian Federation" (On Amending Parts One, Two, Three and the fourth Civil Code of the Russian Federation, as well as in certain legislative acts of the Russian Federation), [https://sozd.duma.gov.ru/bill/47538-6], Accessed 10 April 2020

16 Regulation of the State Duma of the Federal Assembly of the Russian Federation of November 16, 2012, No. 1150-6-ГД “On the procedure for considering the draft federal law N 47538-6 "On amendments to parts one, two, three and four of the Civil Code of the Russian Federation, as well as separate legislative acts of the Russian Federation", Collection of the legislation of the Russian Federation of November 26, 2012, No. 48, Art. 6596

17 Sergeeva, A.P., (ed.), Commentary on the Civil Code of the Russian Federation. Part one, Moscow, Prospect Publishing House, 2018, p. 74 
One of the main mechanisms of cooperation between the European Union and the Russian Federation is the Transport Sector Dialogue. It functions as part of the Roadmap to create a common economic space between Russia and the EU. Since 2010, priority in its work has been put on the implementation of the Partnership for Modernization initiative. In particular, within the framework of this sector dialogue, a special Working Group on modernization was created.

The transport dialogue between Russia and the EU is a mechanism of cooperation between the Ministry of Transport and other state bodies of the Russian Federation, on the one hand, and the European Commission, primarily the General Directorate for Transport, on the other. Its goals are to exchange views and establish strategic relations between partners in the transport and logistics sphere. ${ }^{18}$ It is called upon to ensure harmonization of technical requirements and conditions for transporting goods, synchronizing transport development strategies, exchanging experience and know-how, collaborating in the implementation of major initiatives, such as the "Northern Dimension", and discussing issues that arise at the level of Russia and the European Union in whole ${ }^{19}$.

In the field of labor law, there is also a convergence of Russian legislation with EU legal norms. It is noted that, in principle, the Labor Code of the Russian Federation reproduces almost all institutions of EU labor law. Another thing is how it does this, where there are gaps and shortcomings, how to improve Russian labor legislation to make it more effective by harmonizing it with the European one. Russian legislation in the field of labor protection as a whole meets high standards for ensuring industrial safety and occupational health and is not inferior in this regard to EU labor law standards. However, it is still significantly inferior to Europe in putting these standards into practice. ${ }^{20}$

It is rightly pointed out that the modern similarity of legal regulation of the labor sphere in Russia and the EU is since both sides largely accept international labor standards developed by the International Labour Organisation at the universal level. At the same time, nothing prevents the approximation of these legal orders in the field of labor regulation, which in many ways will make this process even more effective. ${ }^{21}$

18 See further: Entin, M.L.; Istomin, I.A., EU-Russia cooperation in the transport and logistics sector. Analytical reports, Issue 2, September 2012., Moscow, MGIMO-University, European Training Institute at MGIMO (University) of the Ministry of Foreign Affairs of Russia, 2012

19 Emirova, A.E., Transborder problems of formation transport and transit systems, Research of innovative potential of the company and forming directions of its strategic development, 2013, p. 352

20 Kashkin, S.Yu., European Union Labor Law, Moscow, 2009, p. 138

21 Ibid. 
Regarding the sphere of technical regulation, within the EU it is characterized by a developed corresponding institutional system, an effective system of control and punishment, universality, spreading its influence almost on a par with global standardization systems (International Organization for Standardization (ISO), ${ }^{22}$ International Electrotechnical Commission (IEC), ${ }^{23}$ WTO Agreement on Technical Barriers to Trade (TBT WTO), ${ }^{24}$ etc.).

The EU technical regulation system dates back to 1957 when member states initiated negotiations with the European Free Trade Association (EFTA) regarding the harmonization of technical standards. In the future, within the framework of the European Economic Community, the necessary institutional base began to develop, so in 1961 the European Committee for Standardization ${ }^{25}$ was created, in 1972 - the European Committee for Standardization of Electrical Engineering. ${ }^{26}$ In total, 330 technical committees currently operate within the European Union. In their competence, they partly duplicate relevant ISO bodies.

In the Russian Federation, under Article 7 paragraph 8 of the Federal Law «On Technical Regulation», 2002, ${ }^{27}$ international standards should be used in whole or in part as a basis for the development of draft technical regulations, unless the international standards or their sections would be ineffective or unsuitable to achieve those goals established by Article 6 of this federal law, including due to climatic and geographical features of the Russian Federation, technical and (or) technological features.

Therefore, the consideration of a foreign standard as a source of information, the application of the best foreign experience, the borrowing of certain provisions of international standards is one of the ways of developing Russian legislation in this area. When considering the scope of technical regulation in the Russian Federation, it is necessary to take into account the membership of the state in the Eurasian Economic Union (hereinafter — the EAEU). ${ }^{28}$ The EAEU technical

22 International Organization for Standardization (ISO), [https://www.iso.org/ru/home.html], Accessed 10 April 2020

23 International Electrotechnical Commission, [http://www.iec.ch/], Accessed 10 April 2020

24 WTO Technical Barriers to Trade (TBT) Agreement, [https://www.wto.org/english/tratop_e/tbt_e/ tbt_e.htm], Accessed 10 April 2020

25 European Committee for Standardization, [https://www.cen.eu/Pages/default.aspx], Accessed 10 April 2020

26 European Committee for Electrotechnical Standardization, [https://www.cenelec.eu/\#top], Accessed 10 April 2020

27 Federal Law of December 27, 2002 No. 184-Ф3 «On Technical Regulation», Rossiyskaya Gazeta, N 245, December 31, 2002

28 Eurasian Economic Union, [http://www.eurasiancommission.org/], Accessed 10 April 2020 
regulation system is still at the stage of formation, in this regard, law enforcement practice cannot yet be characterized by a high degree of efficiency, like the whole EAEU technical regulation system, which is not comparable with the level of development of the EU technical regulation system.

Since the system of technical regulation of the Russian Federation has the highest level of development in terms of quality and legal support, it largely determines the development of the Eurasian regional system of technical regulation and determines the level of requirements, standards and procedural restrictions in this area, extending to the markets of the EAEU countries.

Interestingly, most of the technical regulations and standards adopted by the Eurasian Economic Commission are "identical" in terms of text and content to EU technical regulations and European standards, as well as "international" standards, which, as mentioned above, are in line with European ones. The practice of developing and adopting technical regulations and standards in the Eurasian Economic Union based on international / European standards creates the main prerequisite for the convergence of technical regulation systems of the EU and the EAEU. In 2017, Eurasian Economic Commission, CEN and CENELEC signed a Memorandum of Understanding. ${ }^{29}$

31 EAEU technical regulations, which entered into force from 2012 to 2015, were developed based on EU framework directives and regulations. From $60 \%$ to $80 \%$ of the EAEU technical standards are identical to European / international standards (depending on the regulations). The total number of Eurasian standards developed based on international and European standards is 5821. For example, the EAEU technical regulation "On the safety of low-voltage equipment" (household appliances and hand tools) practically coincides with the relevant EU directive, and out of 978 standards listed in the list of standards to this technical regulation, 841 are identical to IEC / CENELEC standards. The remaining 137 standards are "modified" based on international / European standards, i.e. according to the text deviate from them no more than $20 \% .^{30}$ This is since initially when forming the national legislation of the Russian Federation, guidelines were taken for harmonizing the national system of technical regulation with international

29 Memorandum of understanding in the field of standardization between the European Committee for Standardization (CEN), the European Committee for Standardization in the Field of Electrical Engineering (CENELEC), the European Institute for Standardization in Telecommunications (ETSI) and the Eurasian Council for Standardization, Metrology and Certification (EASC), Technical Regulation Bulletin, No. 6 (103), 2012

30 Kofner, Yu.K., The system of technical regulation in the EAEU, EAEU Partner, Bulletin of the Eurasian Economic Union, vol. 18, 2018, p. 77 
standards. However, procedurally, the institutions and mechanisms for their implementation are significantly different.

\section{LEGAL ANALYSIS OF THE PROCESS OF LEGAL APPROXIMATION BETWEEN EU AND RUSSIA IN THE HIGHER EDUCATION SPHERE}

In the context of the present research, a special focus should be placed on the study of the field of science and higher education.

Knowledge and innovation are becoming the main factors in the competitiveness of national economies in the growing global processes of globalization. Awareness of the evolutionary nature of the civilizational development of these processes in the European Union gave impetus to the deployment of two interconnected strategic initiatives - the Bologna Declaration (1999) ${ }^{31}$ and the Lisbon Strategy (2000). ${ }^{32}$ The Russian Federation acceded to the Bologna Declaration, and therefore to the Bologna Process in 2003. Its goal is to bring together and harmonize the educational systems of European countries, to create the single European space for higher education. The participation of Russia in the Bologna process makes it possible to carry out structural transformations of higher education according to an agreed system of criteria, standards, and characteristics, which allows Russia to be part of the European educational and scientific space. ${ }^{33}$

The achievement of the Bologna Process is the creation of conditions for each participating country to compare their educational systems and understand their uniqueness and identity, but not completely identical education systems in different countries. The Bologna process is integration for the sake of self-identification and self-awareness in the European context, aiming to create the European scientific and educational space to increase the competitiveness of European higher education, while the main priority of the Lisbon Strategy is to turn Europe into a dynamic knowledge economy. Measures to implement both mechanisms of cooperation are aimed at developing the intellectual potential of the European region, namely, its formation and use for the stability of economic growth, increasing the

31 Joint Declaration of the European Ministers of Education convened in Bologna on 19 June 1999, [http://www.ehea.info/media.ehea.info/file/Ministerial_conferences/02/8/1999_Bologna_Declaration_English_553028.pdf], Accessed 10 April 2020

32 Lisbon Strategy, 2000, [http://www.europarl.europa.eu/summits/lis1_en.htm], Accessed 10 April 2020

33 See: Russia in the European Higher Education Area, Artamonova, Yu.D. et al. (eds.), Moscow, 2015, [https://istina.msu.ru/media/publications/book/bbc/575/10628419/Russia_in_european.pdf], Accessed 10 April 2020 
number of new jobs for highly skilled workers, as well as ensuring social consent of the European society. However, one should not idealize the Bologna process as it is characterized by inconsistency and complexity.

By joining the Bologna process, Russia has initiated some normative measures to ensure compliance of domestic legislation with the provisions of the Bologna Declaration. Initially, the Government of the Russian Federation approved the "Priority Directions for the Development of the Education System of the Russian Federation", among which were the following:

- meeting the demands of the modern labor market for professional education programs (introduction of professional standards by 2008, new educational standards by 2010);

- changing the concept and structure of the state educational standard (expanding the freedoms of educational organizations, switching to "framework" educational standards);

- introduction of a two-tier higher professional education;

- creation of conditions for academic mobility of students (internal and external);

- providing conditions for lifelong education;

- credit-modular construction of professional educational programs. ${ }^{34}$

On 15 February 2005, the Ministry of Education and Science of Russia issued an Order "On the implementation of the provisions of the Bologna Declaration in the higher education system of the Russian Federation", which approved the Action Plan ${ }^{35}$ for the implementation of the Bologna Declaration in the higher education system of the Russian Federation for 2005-2010.36

The Plan identified several priority activities, here are some of them:

- amendments to the Laws "On Education" and "On Higher and Postgraduate Professional Education”;

34 Ibid.

35 Order of the Ministry of Education and Science of the Russian Federation of February 15, 2005 No. 40 "On the implementation of the provisions of the Bologna Declaration in the system of higher professional education of the Russian Federation", Bulletin of the Ministry of Education and Science of the Russian Federation, No. 4, 2005

36 Gorylev, A.I., Legal regulation of the participation of Russian universities in the Bologna process, Bulletin of the Nizhny Novgorod University. N.I. Lobachevsky, no. 6-1, 2009, p. 41 
- development, approval, and implementation of state educational standards of higher professional education of the third generation, formed based on the competency-based approach and credit system;

- mandatory use of the credit system (ECTS);

- creation of a system of comparable criteria, methodologies, and technologies for assessing the quality of education to ensure harmonization of the Russian system for assessing the quality of education with European systems;

- promoting the development of academic mobility of students and university lecturers. $^{37}$

Currently, the desire to ensure compliance with the Bologna process in every possible way permeates the measures of legal regulation of higher education in the Russian Federation. In particular, in the Concept of the Federal Target Program for the Development of Education for 2016-2020, approved by Decree of the Government of the Russian Federation of 29 December 2014 N 2765-r, ${ }^{38}$, as one of the main results of the implementation of the Program, that as part of measures on development and dissemination of new technologies and forms of organization of the educational process by creating a regulatory and methodological base in the system of vocational education, advanced training of managers and scientific and pedagogical workers, analytical support of these processes, it is indicated the implementation of basic requirements of the Bologna process in all institutions of higher education and secondary vocational education.

The Bologna process includes many different mechanisms for its implementation, for example, the national qualifications framework, a three-tier system of higher education, the European system of accumulation and transfer of credit units (ECTS), mechanisms for recognition of periods of study at other universities and others. Hence, it seems necessary to analyze the implementation of some of these mechanisms in the Russian Federation in more detail.

In 2008, Recommendation on the establishment of the European Qualifications Framework for Lifelong Learning $(\mathrm{EQF})^{39}$ formally entered into force. Since then it allows us to compare qualifications and educational degrees, and to create the

$37 \quad$ Ibid.

38 Regulation of the Government of the Russian Federation of December 29, 2014, N 2765-r «On the Concept of the Federal Target Program for the Development of Education for 2016 - 2020", Collection of the legislation of the Russian Federation, No. 2, 01/12/2015, Art. 541

39 Recommendation of the European Parliament and of the Council of 23 April 2008 on the establishment of the European Qualifications Framework for lifelong learning (Text with EEA relevance), OJ C $111,6.5 .2008$, p. $1-7$ 
basis for mutual recognition of higher education programs of different countries..$^{40}$ The National Qualifications Frameworks (NQF) have already been established in most European countries. In the Russian Federation, the National Qualifications System (NQF) is being introduced, that is, a set of interrelated documents, state-public institutions and events, in particular, consisting of the National Qualifications Framework, ${ }^{41}$ industry qualifications frameworks, professional stand$\operatorname{ards}^{42}$ and other components. However, these measures have not yet been fully developed and implemented.

It should be noted the success in introducing a three-tier structure of Russian higher education. In particular, the Federal Law of 29 December 2012 No. 273 "On Education in the Russian Federation" ${ }^{43}$ enshrined provisions on regulatory deadlines for the development of educational programs. Previously, the legislation fixed exact terms of study in higher education programs: undergraduate 4 years, master's programs -2 years. According to Article 12 paragraph 7 of the specified Federal Law, organizations carrying out educational activities under state-accredited educational programs (except for educational programs of higher education, implemented based on educational standards approved by educational institutions of higher education independently), develop educational programs under federal state educational standards and taking into account relevant basic educational programs.

Hence, according to paragraph 3.3 of the Federal State Educational Standard for Higher Education in the direction of preparation 40.03.01 «Jurisprudence» (undergraduate level), ${ }^{44}$ the term for receiving education in a full-time undergraduate program, including vacations provided after passing the state final certification, regardless of the educational technology, is 4 years; in full-time or part-time education, regardless of the educational technologies used, it is increased by at least 6 months and no more than 1 year, compared with the term for full-time education.

$40 \quad$ See: Artamonova, op. cit., note 33

41 Russian NQF was developed based on the PCA and interaction of the Ministry of Education and Science of the Russian Federation and the Russian Union of Industrialists and Entrepreneurs, taking into account the experience of building the European Qualifications Framework

42 Regulation of the Government of the Russian Federation of January 22, 2013 No. 23 "On the Rules for the Development and Approval of Professional Standards”, Collection of Legislation of the Russian Federation, January 28, 2013, No. 4, Art. 293

43 Federal Law of December 29, 2012, No. 273-Ф3 “On Education in the Russian Federation”, Collection of Legislation of the Russian Federation, December 31, 2012, No. 53 (part 1), Art. 7598

44 Order of the Ministry of Education and Science of Russia No. 1511 of 12/01/2016 "On the approval of the federal state educational standard of higher education in the field of preparation 40.03.01 Jurisprudence (undergraduate level)", [https://xn--80abucjiibhv9a.xn--p1ai/\%D0\%B4\%D0\%BE\%D0\% BA\%D1\%83\%D0\%BC\%D0\%B5\%D0\%BD\%D1\%82\%D1\%8B/9604], Accessed 10 April 2020 
The specific term of education and the scope of the specialty program, implemented in one academic year, in the part-time form of study under an individual student's plan, are determined by the organization independently within the time limits established by this paragraph.

In the field of legal higher education, national admissibility and expediency acceptable within the framework of the Bologna process also find its manifestation. For example, along with the Federal State Educational Standards for bachelor and master programs, federal state educational standards of higher education were also adopted in the specialty 40.05.02 "Law enforcement activities» (specialist program $)^{45}$ and in the specialty 40.05 .01 «Legal support of national security» (specialist program). ${ }^{46}$ These documents determined a full-time study period of five years.

The 2012 Federal Law, having established the three-tier structure of higher education, also equated postgraduate period with one of the study cycles. Under Article 108 paragraph 1 point 6 , postgraduate professional education in the postgraduate study was equated to higher education, i.e. preparation of highly qualified staff in study programs for scientific and pedagogical personnel.

Based on this, postgraduate programs began to be developed and implemented by educational and scientific organizations:

- by the List of areas of study in postgraduate study, approved by the Order of the Ministry of Education and Science of Russia (harmonized with the international Fields of Science and Technology classifier of the Organization for Economic Cooperation and Development (OECD) - FOS-2007 $\left.{ }^{47}\right)^{48}$;

- based on the Federal State Educational Standards in the areas of postgraduate studies approved by the orders of the Ministry of Education and Science of

45 Order of the Ministry of Education and Science of Russia No. 1424 of November 16, 2016 "On the approval of the federal state educational standard of higher education in the specialty 40.05.02 Law enforcement activities (specialist program)", [https://xn--80abucjiibhv9a.xn--p1ai/\%D0\%B4\%D0\%BE $\% \mathrm{D} 0 \% \mathrm{BA} \% \mathrm{D} 1 \% 83 \% \mathrm{D} 0 \% \mathrm{BC} \% \mathrm{D} 0 \% \mathrm{~B} 5 \% \mathrm{D} 0 \% \mathrm{BD} \% \mathrm{D} 1 \% 82 \% \mathrm{D} 1 \% 8 \mathrm{~B} / 9609]$, Accessed 10 April 2020

46 Order of the Ministry of Education and Science of the Russian Federation of December 19, 2016 No. 1614 "On approval of the federal state educational standard of higher education in the specialty 40.05.01 Legal support of national security (specialist program)", [http://fgosvo.ru/uploadfiles/ fgosvospec/400501.pdf], Accessed 10 April 2020

47 Fields of Science and Technology classifier of the Organization for Economic Cooperation and Development (OECD) — FOS-2007, [https://www.oecd.org/science/inno/38235147.pdf], Accessed 10 April 2020

48 Order of the Ministry of Education and Science of the Russian Federation of September 12, 2013 No. 1061 "On approval of the lists of specialties and areas of higher education training", [https:// rg.ru/2013/11/01/obr-napravlenia-dok.html], Accessed 10 April 2020 
Russia, or based on educational standards independently set by educational institutions of higher education that have been given this right by federal legislation, and besides the federal state educational standards determine the modern universal competencies necessary for a postgraduate student, as well as research and teaching competencies. ${ }^{49}$

For example, according to the Federal state educational standard of higher education in the direction of preparation 40.06 .01 «Jurisprudence» (the level of preparation of highly qualified staff), ${ }^{50}$ as a result of the acquisition of postgraduate educational programs based on the results of the state final certification, graduates will be awarded the qualification "Researcher. Lecturer-researcher" with the issuance of the appropriate diploma.

One of the key aspects of the development of the education system in the European Union is lifelong learning. In Russia, the formation of a lifelong learning system is still in its infancy. However, this type of education is reflected in domestic law. By Article 10 paragraph 7 of the Federal Law "On Education in the Russian Federation" of 2012, the education system creates the conditions for lifelong learning through the implementation of basic educational programs and various additional educational programs, providing the opportunity to simultaneously acquisition of several educational programs, as well as taking into account existing education, qualifications, and practical experience during the study. However, necessary organizational, regulatory and methodological mechanisms for the implementation of this legislative norm have not yet been created.

Within the framework of the Bologna process, great attention is paid to ensuring the quality of education. In particular, the national quality assurance system is implemented through licensing and accreditation systems.

Under Article 91 paragraph 1 of the 2012 Federal Law "On Education in the Russian Federation", educational activities are subject to licensing in accordance with the legislation of the Russian Federation on licensing certain types of activities, taking into account the features established by this article. Licensing of educational activities is carried out by type of education, by the level of education, by profession, specialty, areas of study (for vocational education), by subspecies of further education. The purpose of state accreditation of educational activities

\footnotetext{
49 See: Artamonova, op. cit., note 33

50 Order of the Ministry of Education and Science of the Russian Federation of December 5, 2014 No. 1538 «On approval of the federal state educational standard of higher education in the field of training 40.06.01 Jurisprudence (the level of preparation of highly qualified staff)», [http://fgosvo.ru/uploadfiles/fgosvoaspism/400601.pdf], Accessed 10 April 2020
} 
is to confirm compliance with federal state educational standards of educational activities in the main educational programs and the preparation of students in educational organizations.

For concretization of these legislative provisions and regulate the relevant procedures, there were adopted several acts of delegated legislation: Regulations of the Government of the Russian Federation of 18 November 2013 No. 1039 "On State Accreditation of Educational Activities" "51 and of 28 October 2013 No. 966 "On Licensing of Educational Activities", 52 which approved relevant Regulations.

The Federal Law in Article 95 also provides for the possibility of an independent assessment of the quality of education. Besides, Article 96 paragraph establishes that organizations engaged in educational activities may receive public accreditation in various Russian, foreign and international organizations. Article 96 paragraph 4 ensures the possibility of undergoing professional and public accreditation of basic professional educational programs, basic professional training programs and (or) additional professional programs as recognition of the quality and level of preparation of graduates who have acquired such educational programs in a specific organization engaged in educational activities that meet the requirements of professional standards, labor market requirements for specialists, workers and employees of a relevant profile.

Thus, the current Russian legislation provides an integrated system of various procedures for ensuring the quality of education under the provisions of European standards:

- licensing of educational activities;

- state control (supervision) in the field of education;

- state accreditation of educational activities, mandatory for all educational institutions;

- public accreditation of educational organizations by independent organizations;

- voluntary professional accreditation of educational programs by employers;

51 Regulation of the Government of the Russian Federation of November 18, 2013 No. 1039 "On state accreditation of educational activities", Collection of legislation of the Russian Federation, November 25, 2013, N 47, Art. 6118

52 Regulation of the Government of the Russian Federation of October 28, 2013 No. 966 "On the licensing of educational activities", Collection of the legislation of the Russian Federation, 04.11.2013, N 44, Art. 5764 
- an independent assessment of the quality of education carried out to determine the conformity of the education provided to the needs of an individual or a legal entity whose interests educational activities are carried out.

In general, the ongoing modernization of the legislation regulating the sphere of higher education complies with the requirements of the Bologna process, and its basic principles themselves have become an integral part of Russian educational law. This is due to the fact that the initial paradigms of such modernization were focused on integrating the national education system into the single European space for higher education, including on the basis of bilateral EU-Russian cooperation mechanisms. However, there remains a need for further improvement of the legislation of the Russian Federation on education for its optimization and conformity with recent European norms and best practices.

\section{CONCLUSION}

Despite the existing problems in mutual relations, the European Union remains the main economic and political partner for Russia on the European continent. The EU-Russia partnership is supposed to be built based on contractual relations, which in the long run facilitated the development of joint efforts in various fields of cooperation, including the sphere of legal approximation.

Approximation of national legislation with the EU acquis is a consistent process of convergence of the legal system of the state, including legislation, lawmaking, legal technics, law enforcement practice under the criteria set by the Union. Therefore, the process of legal approximation should be approached more broadly, since it includes a specific variety of processes of changing the legal system, the key component of which is an active and systematic impact on the national legal system and its segments to ensure an appropriate degree of functional and (or) structural similarity of the national legal order with chosen political means of a model analog and thus providing controllability of the process of development of society in the projected directions.

As international experience testifies, the mechanism of legal approximation depends on the characteristics of the legal, political, economic system of each of the states. For the Russian Federation, approximation of national legislation with law of the European Union is of particular importance and relevance, since this process involves not only the creation of a legal framework for relations with the EU but also the achievement of other goals important for the state, namely: the creation of mechanisms for implementing economic reforms, increasing the competitiveness of the economy and promoting foreign investment in the country, 
the development of foreign trade between the Russian Federation and the Union and the entire spectrum of mutual trade and economic mutual relations, further democratization of social processes, development of the basic principles of the functioning of civil society per European standards, the development of the higher education system.

Work on the approximation of the Russian legislation with the EU normative prescriptions should be continued, and the existing successes and achievements to be preserved and developed. However, Russia should accept new challenges not only transferring European experience to her legal system but also offering her works, achievements, proposals, the vision of problems to the European community. Hence it appears necessary to achieve a harmonious combination of European innovations and the best domestic traditions.

\section{REFERENCES}

\section{BOOKS AND ARTICLES}

1. Baltutite, I.V., The contingence of corporate regulation in the being reformed Civil Code of the Russian Federation with the provisions of the Corporate law of the European Union, Science Journal of VolSU, Series 5: Jurisprudence, no. 4, 2013, pp. 22-26

2. Emirova, A.E., Transborder problems of formation transport and transit systems, Research of innovative potential of the company and forming directions of its strategic development, 2013, pp. 351-355

3. Entin, M.L.; Istomin, I.A., EU-Russia cooperation in the transport and logistics sector. Analytical reports, Issue 2, September 2012., Moscow, MGIMO-University, European Training Institute at MGIMO (University) of the Ministry of Foreign Affairs of Russia, 2012

4. Gorylev, A.I., Legal regulation of the participation of Russian universities in the Bologna process, Bulletin of the Nizhny Novgorod University. N.I. Lobachevsky, no. 6-1, 2009, pp. 37-44

5. Haukkala, H., Debating Recent Theories of EU-Russia Interaction. Cooperation and Confict, vol. 43, no. 1, 2008, pp.109-12

6. Haukkala, H., The European Union as a Regional Normative Hegemon: The Case of European Neighbourhood Policy, Europe-Asia Studies, vol. 60, no. 9, 2008, pp. 1601-1622

7. Hillion, Ch., The evolving system of the EU external relations as evidenced in the EU partnerships with Russia and Ukraine, Leiden, 2005

8. Kashkin S.Yu., Kalinichenko, P.A., Harmonization of the legislation of Russia and the European Union, as a key component of their effective mutual development in the XXI century, Law and state: theory and practice, 2005, no. 4, pp. 100-129

9. Kashkin, S.Yu., European Union Labor Law, Moscow, 2009

10. Kashkin, S.Yu., Strategy and mechanisms for harmonizing the legislation of Russia and the European Union as key components of their effective mutual development in the 21st century, Moscow, Russian-European Center for Economic Policy, 2006 
11. Kazimirova, N.G., Russia in the of continental law: reception and perspectives of reforming of the legislation, Economic, Legal, Social-Political and Psychological Problems of Development of the Modern Society, 2015, pp. 171-175

12. Kofner, Yu.K., The system of technical regulation in the EAEU, EAEU Partner, Bulletin of the Eurasian Economic Union, vol. 18, 2018

13. Manners, I., Normative Power Europe: A Contradiction in Terms? Journal of Common Market Studies, vol. 40, no. 2, 2002, pp. 235-258

14. Sergeeva, A.P., (ed.), Commentary on the Civil Code of the Russian Federation. Part one, Moscow, Prospect Publishing House, 2018

15. Yun, S.M. (ed.), Russia and the European Union: Textbook, Tomsk, Publishing house of Tomsk University, 2014

\section{EU LAW}

1. Agreement on partnership and cooperation establishing a partnership between the European Communities and their Member States, of one part, and the Russian Federation, of the other part, OJ L 327, 28.11.1997, p. 3-69

2. Recommendation of the European Parliament and of the Council of 23 April 2008 on the establishment of the European Qualifications Framework for lifelong learning (Text with EEA relevance), OJ C 111, 6.5.2008, p. 1-7

3. Memorandum of understanding in the field of standardization between the European Committee for Standardization (CEN), the European Committee for Standardization in the Field of Electrical Engineering (CENELEC), the European Institute for Standardization in Telecommunications (ETSI) and the Eurasian Council for Standardization, Metrology and Certification (EASC), Technical Regulation Bulletin, no. 6 (103), 2012

\section{LIST OF NATIONAL REGULATIONS, ACTS AND COURT DECISIONS}

1. Regulation of the Government of the Russian Federation of November 18, 2013 No. 1039 "On state accreditation of educational activities", Collection of legislation of the Russian Federation, November 25, 2013, N 47, Art. 6118

2. Decree of the President of the Russian Federation "On improving the Civil Code of the Russian Federation” dated July 18, 2008 No. 1108, Rossiyskaya Gazeta, 2008, no. 155

3. Regulation of the State Duma of the Federal Assembly of the Russian Federation of November 16, 2012, N. 1150-6-ГД “On the procedure for considering the draft federal law N 47538-6 "On amendments to parts one, two, three and four of the Civil Code of the Russian Federation, as well as separate legislative acts of the Russian Federation”, Collection of the legislation of the Russian Federation of November 26, 2012, No. 48, Art. 6596

4. Federal Law of December 27, 2002 No. 184-Ф3 «On Technical Regulation», Rossiyskaya Gazeta, N 245, December 31, 2002

5. Order of the Ministry of Education and Science of the Russian Federation of February 15, 2005 No. 40 "On the implementation of the provisions of the Bologna Declaration in the system of higher professional education of the Russian Federation”, Bulletin of the Ministry of Education and Science of the Russian Federation, No. 4, 2005 
6. Regulation of the Government of the Russian Federation of December 29, 2014, N 2765$\mathrm{r}$ «On the Concept of the Federal Target Program for the Development of Education for 2016 - 2020", Collection of the legislation of the Russian Federation, No. 2, 01/12/2015, Art. 541

7. Regulation of the Government of the Russian Federation of January 22, 2013 No. 23 "On the Rules for the Development and Approval of Professional Standards", Collection of Legislation of the Russian Federation, January 28, 2013, No. 4, Art. 293

8. Federal Law of December 29, 2012, No. 273-Ф3 "On Education in the Russian Federation”, Collection of Legislation of the Russian Federation, December 31, 2012, No. 53 (part 1), Art. 7598

9. Regulation of the Government of the Russian Federation of October 28, 2013 No. 966 "On the licensing of educational activities", Collection of the legislation of the Russian Federation, 04.11.2013, N 44, Art. 5764

\section{WEBSITE REFERENCES}

1. Artamonova, Yu.D. et al. (eds.), Russia in the European Higher Education Area, Moscow, 2015, [https://istina.msu.ru/media/publications/book/bbc/575/10628419/Russia_in_european.pdf], Accessed 10 April 2020

2. Draft Federal Law No. 47538-6 "On Amending the Civil Code of the Russian Federation, Certain Legislative Acts of the Russian Federation and on the Recognition of Certain Legislative Acts (Provisions of Legislative Acts) of the Russian Federation” (On Amending Parts One, Two, Three and the fourth Civil Code of the Russian Federation, as well as in certain legislative acts of the Russian Federation), [https://sozd.duma.gov.ru/bill/47538-6], Accessed 10 April 2020

3. Eurasian Economic Union, [http://www.eurasiancommission.org/], Accessed 10 April 2020

4. European Committee for Electrotechnical Standardization, [https://www.cenelec.eu/\#top], Accessed 10 April 2020

5. European Committee for Standardization, [https://www.cen.eu/Pages/default.aspx], Accessed 10 April 2020

6. Fields of Science and Technology classifier of the Organization for Economic Cooperation and Development (OECD) — FOS-2007, [https://www.oecd.org/science/inno/38235147. pdf], Accessed 10 April 2020

7. International Electrotechnical Commission, [http://www.iec.ch/], Accessed 10 April 2020

8. International Organization for Standardization (ISO), [https://www.iso.org/ru/home.html], Accessed 10 April 2020

9. Joint Declaration of the European Ministers of Education convened in Bologna on 19 June 1999, [http://www.ehea.info/media.ehea.info/file/Ministerial_conferences/02/8/1999_Bologna_Declaration_English_553028.pdf], Accessed 10 April 2020

10. Kalinichenko, P.A., Europeanization of Russian law, [https://publishup.uni-potsdam.de/opus4ubp/frontdoor/deliver/index/docId/5663/file/belling_online_S65_86.pdf], Accessed 10 April 2020 
11. Kulik, S.A., Russia - European Union: On the Forks of "Strategic Partnership", INSOR, 2010, June, [http://www.insor-russia.ru/files/Russia_EU_Kulik_.pdf\#3], Accessed 10 April 2020

12. Lisbon Strategy, 2000, [http://www.europarl.europa.eu/summits/lis1_en.htm], Accessed 10 April 2020

13. Order of the Ministry of Education and Science of Russia No. 1424 of November 16, 2016 "On the approval of the federal state educational standard of higher education in the specialty 40.05.02 Law enforcement activities (specialist program)", [https://xn--80abucjiibhv9a.xn--p1ai/\%D0\%B4\%D0\%BE\%D0\%BA\%D1\%83\%D0\%BC\%D0\%B5\%D0\%BD\%D1\%82\%D1\%8B/9609], Accessed 10 April 2020

14. Order of the Ministry of Education and Science of Russia No. 1511 of 12/01/2016 "On the approval of the federal state educational standard of higher education in the field of preparation 40.03.01 Jurisprudence (undergraduate level)", [https://xn--80abucjiibhv9a.xn--p1ai/\%D0\%B4\%D0\%BE\%D0\%BA\%D1\%83\%D0\%BC\%D0\%B5\%D0\%BD\%D1\%82\%D1\%8B/9604], Accessed 10 April 2020

15. Order of the Ministry of Education and Science of the Russian Federation of December 19, 2016 No. 1614 "On approval of the federal state educational standard of higher education in the specialty 40.05.01 Legal support of national security (specialist program)", [http:// fgosvo.ru/uploadfiles/fgosvospec/400501.pdf], Accessed 10 April 2020

16. Order of the Ministry of Education and Science of the Russian Federation of September 12, 2013 No. 1061 "On approval of the lists of specialties and areas of higher education training”, [https://rg.ru/2013/11/01/obr-napravlenia-dok.html], Accessed 10 April 2020

17. Order of the Ministry of Education and Science of the Russian Federation of December 5, 2014 No. 1538 «On approval of the federal state educational standard of higher education in the field of training 40.06.01 Jurisprudence (the level of preparation of highly qualified staff)», [http://fgosvo.ru/uploadfiles/fgosvoaspism/400601.pdf], Accessed 10 April 2020

18. WTO Technical Barriers to Trade (TBT) Agreement, [https://www.wto.org/english/tratop_e/tbt_e/tbt_e.htm], Accessed 10 April 2020 